\title{
Diversity of Heterotrophic Bacteria Isolated from Water in the Paddy Rice Fields of Southern Brazilian
}

\author{
Jeremias Pakulski Panizzon ${ }^{1}$, Vilmar Machado ${ }^{1, *}$, Vera Regina Mussoi Macedo ${ }^{2}$, Lidia Mariana Fiuza $^{1,2}$ \\ ${ }^{1}$ Laboratório de Microbiologia e Toxicologia, PPG em Biologia, Universidade do Vale do Rio dos Sinos, UNISINOS, C.P. 275, \\ CEP 93001-970, São Leopoldo, RS, Brasil \\ ${ }^{2}$ EEA/Instituto Riograndense do Arroz, C.P. 29, CEP 94930-030, Cachoeirinha, RS, Brasil
}

\begin{abstract}
This study evaluated the effects of physic-chemical variables on the diversity of bacterial communities present in the water utilized to irrigate rice field and in the water drained back into the water source. The samples were collected between the months of October and April of the year 2009/2010 in three rice producing areas in the district of Caraá, Campo Bom and Esteio, all located in the Basin of the Rio dos Sinos. The data was analysed utilizing Multivariate Analyses (CCA and DCA), Jaccard Distance and Variance Analyses. The abundance of the bacterial colonies was greater in the irrigation water than in that within the rice field or in the drainage. $(\mathrm{F} 1,9=7.21 \mathrm{p}<0.05) ; 48.6 \%$ were found in the irrigation channel, $25.7 \%$ in the water within the field and $25.7 \%$ in the water returned to the river (drainage). Colonies of 21 species were registered and of these: 16 were in the irrigation channels; 14 in the water in the rice field and 18 in the drainage water. The estimated diversity was superior in the irrigation channels $(\mathrm{H}=2.68)$ when compared with the values obtained in the drainage water $(\mathrm{H}=2.25)$. The results demonstrated that the samples from the irrigation water and the drainage water differ in the composition of the species in all the locations analysed. The two initial axes generated by Detrended Correspondence Analysis explain $56 \%$ of the observed variation between the locations. The most important variables for the ordination and correlation with the axis were the $\mathrm{pH}$ and Nitrogen. The results show that rice bacteria communities contain several species but few are abundant, such as species of Bacillus, Lactobacillus and Pseudomonas. The reduction in colony abundance on the drainage water shows the ability of the rice field to filter some bacterial species.
\end{abstract}

Keywords Bacterial, Rice Field, Irrigation, Diversity, Physical-Chemicals Parameters

\section{Introduction}

Bacteria present a degree of diversity without parallel in the biological world - they are found in all environments even those that are inhospitable to other live organisms. Studies on the factors that influence the distribution, diversity, and structure are relatively recent, especially those that involve molecular methods. A better understanding of the environmental factors that influence changes in the diversity of the bacterial communities is very important because they realize functions that are indispensable for maintenance of the ecosystems[1-3]. According to Horner-Devine et al.[4], one of the important points of the bacterial ecology is the description of the distribution of the bacterial diversity along the environmental gradients.

In freshwater systems these studies can also contribute to activities designed to monitor the water quality and the impact of human activities on that quality[5,6]. Studies on the composition of the bacterial communities (beta diversity) are

* Corresponding author:

vmachado27@hotmail.com (Vilmar Machado)

Published online at http://journal.sapub.org/microbiology

Copyright (C) 2012 Scientific \& Academic Publishing. All Rights Reserved important for the development of strategies to preserve the biodiversity and for the management of these communities during bioremediation activities and can contribute to the development of theoretical models of the ecology of the microorganisms[7-9].

Although in some agricultural areas, studies have been carried out to analyze the effects on bacterial diversity of the chemical substances used for fertilization and pest control [10] arrangements associated to cultivation[11-14], these studies mainly analyze the impact of different factors on the biodiversity of the bacteria in the soil. In areas of rice cultivation the studies are concerned principally with the soil bacteria involved in the processing of the rice plant residues ([15-19], rather than the biodiversity present in the water [20-22]. In this context, any study that helps to evaluate the factors that influence the composition of the bacterial communities in the water utilized for irrigation of rice crops is relevant, especially when one considers the small number of studies available on the subject.

The cultivation of irrigated rice is considered worldwide as one of the agricultural activities that consume most water. In Brazil approximately $11,000 \mathrm{~kg} /$ ha are produced annually $-60 \%$ in the State of Rio Grande do Sul[23]. The importance of water for this culture is associated with the increase in the 
availability of nutrients, the control of weeds and the regulation of the thermal alterations in the soil. Notwithstanding the importance of water for the productivity of rice field, some problems arise from irrigation especially the possibility of contamination from polluted irrigation water[24,25], the contamination of water resources by chemical substances used for fertilization of the soil and/or pest control[26,27]; and the impact on the biodiversity of the micro-organisms [22].

This study was realized with the objective of evaluating the diversity of the bacterial communities found in the water supplied for irrigation of rice fields and in that water returned to the river after passing through the cultivation area. The fundamental aspect of this study was to obtain answers to the following questions; (i) Is the bacterial diversity different in the water entering the rice field for irrigation and that same water when it exits the cultivation area having irrigated the crop? and (ii) What environmental variables influence the composition of the cultivated bacterial communities?

\section{Materials and Methods}

Area Studied: The hydrographic basin of the Rio-dosSinos is located in the Northeast of the State of Rio Grande do Sul (RS), between the $29^{\circ}$ and $30^{\circ}$ south parallels. It covers an area of $3820 \mathrm{~km}^{2}$ - the principal waterway extends $190 \mathrm{~km}$ from its origin in the district of Caraá to its discharge in the delta of the Jacui river. In the Sinos Basin, thirty-two districts with a total of 975.000 inhabitants are located - 13 directly watered by the river from which they obtain water for treatment and consumption and use for sewage disposal. The rice fields draw water from the same river for irrigation and return it to the river afterwards.

The locations analyzed in the district of Caraá $-R S$ were: Entrance of the irrigation channel $\left(29^{\circ} 46^{\prime} 53,97^{\prime} ' \mathrm{~S}\right.$ and $\left.50^{\circ} 26^{\prime} 52,21^{\prime \prime} \mathrm{W}\right)$; The field rice $\left(29^{\circ} 47^{\prime} 02,50^{\prime \prime} \mathrm{S}\right.$ and $\left.50^{\circ} 26^{\prime} 49,15^{\prime \prime} \mathrm{W}\right)$; and the drainage channel ${ }^{\circ} 47^{\prime} 04,20^{\prime \prime} \mathrm{S}$ and $\left.50^{\circ} 26^{\prime} 53,93^{\prime \prime} \mathrm{W}\right)$. In the district of Campo Bom (RS) the points of analyses were: Entrance of the irrigation channel $\left(29^{\circ} 42^{\prime} 05,98^{\prime \prime} \mathrm{S}\right.$ and $\left.51^{\circ} 02^{\prime} 56,39^{\prime}{ }^{\prime} \mathrm{W}\right)$; rice field $\left(29^{\circ} 42^{\prime} 10\right.$, 04 'S and $51^{\circ} 02,59,78^{\prime \prime} \mathrm{W}$ ); and the drainage channel $\left(29^{\circ} 42^{\prime} 06,06^{\prime \prime} \mathrm{S}\right.$ and $\left.51^{\circ} 03^{\prime} 12,75^{\prime} \mathrm{W}\right)$. In the district of Esteio $(R S)$ the points of analysis were: The entrance of the irrigation channel $\left(29^{\circ} 50^{\prime} 55,23^{\prime \prime} \mathrm{S}\right.$ and $\left.51^{\circ} 11^{\prime} 32,08^{\prime \prime} \mathrm{W}\right)$; the rice field (29 $50^{\prime} 48,28^{\prime \prime} \mathrm{S}$ and $51^{\circ} 11^{\prime} 49,49^{\prime}$ ' $\left.\mathrm{W}\right)$; and the drainage channel (29 $50^{\circ} 45,50^{\prime}$ 'S and $51^{\circ} 11^{\prime} 52,86^{\prime}$ ' $\mathrm{W}$ ).

Water Samples: The water samples were collected between October and April of the agricultural years 2009/2010 in three separate irrigated rice fields located in the districts of Caraá, Campo Bom and Esteio (Figure 1). The sample collection was realized once every fortnight in the main irrigation channel, in the sheet of ground-water amongst the plants and in the drainage channel (return of the water to the river).

From $100 \mathrm{~mL}$ of the sampled water $500 \mu \mathrm{L}$ was mixed with $4.5 \mathrm{~mL}$ of saline solution $(\mathrm{NaCl} 10 \%)$ to produce a dilute solution of $1 / 10^{2}$. Then $100 \mu \mathrm{L}$ was placed in a Petri dish containing Agar Nutrient [digestible gelatin enzyme $(5 \mathrm{~g} / \mathrm{L})$, meat extract $(3 \mathrm{~g} / \mathrm{L})$ and Agar $(15 \mathrm{~g} / \mathrm{L})]$, and incubated in a bacteriological oven at $30^{\circ} \mathrm{C}$ for 24 hours. The colonies grown separately were numbered with a colony counter and the bacterial cells analyzed cytologically with an optical microscope $(1000 \mathrm{X})$. The spore-producing bacteria were separated by pasteurization and both groups (spore- producers and non spore-producers) were identified by cellular morphology, physiological and biochemical characteristics in accordance with the International Methods of Bacterial Classification described in "Bergey's Manual of Determinative Bacteriology" [28]. The gram-negative bacteria were identified by the API Biomerieux $20 E$ method and the level of species determined subsequently using the API Web software.

Parameters analyzed: In the EEA-IRGA Soil and Water Analysis Laboratory, the physic-chemical elements that we analyzed were: $\mathrm{pH}$, Nitrogen (mg / L), Phosphorus (mg / L), Magnesium (mg / L), Potassium (mg / L), Carbon (mg / L) and solids $(\mathrm{mg} / \mathrm{L})$. The procedures used to estimate the physical/chemical variables were those defined by Tedesco et al. [29].

Statistical Analysis: Variance Analysis (ANOVA - P < 0.05 ) was utilized to evaluate the differences in the abundance of the bacterial colonies present in the water supplied for irrigation, in the plantation itself and in the drainage outlet. The diversity in the rice fields was analyzed using the Shannon and Evenness[30] indices, calculated separately for each water origin and sites. We also analyzed the diversity by the Jaccard[30] coefficient using the total abundance values for each environment (location and water origin) and displaying the results in the form of a dendrogram. The metric UPGMA connection method was used to attribute similarity between the pairs in a less extreme manner. The cluster analysis was made with the NTSYS 2.1 program[31].

The distribution pattern of the taxa between the sample areas and water origin was assessed by Detrended Correspondence Analysis, DCA[32,33], and the values were transformed by the expression $\log _{10}(\mathrm{x}+1)$ to compensate for the deviations caused by the low or higher abundance[34]. PC - ORD 4.0[35] was utilized for the DCA analysis.

The influence of the physic-chemical parameters on the abundance of the principal species was quantified by the Canonical Correspondence Analysis (CCA) method using the PC-ORD program[35]. The CCA made it possible to produce an analysis of direct ordination of the gradients, explaining the distribution of the species in relation to the environmental variables. The significance of the principal axis of the canonical ordination was evaluated by the Monte Carlo [34] permutation test. For this analysis we used species with more than five colonies per point.

\section{Results}

Colonies of a total of 21 species were registered; of these, 16 were found in the incoming irrigation water, 14 in the 
water within the fields and 18 in the drainage water (Table 1). The bacterial abundance, considering all the samples analyzed, was greater in the irrigation water than in the waters within the plantation and in the drainage $\left(\mathrm{F}_{1,9}=7.21 \mathrm{p}<\right.$ $0.05)$. Of this total, $48.6 \%$ of the colonies were found in the irrigation channel, $25.7 \%$ in the water sheet around the plants and $25.7 \%$ in the water returned to the river (drainage).

The estimated diversity was greater in the irrigation channels $(\mathrm{H}=2.68)$ than the values obtained in the drainage water $(\mathrm{H}=2.50)$. The equitability index indicates that the distribution of the species is similar in the two locations $(E=$ 0.86 and 0.82 ). The observed values of the general diversity of the water around the plants is closer to that observed in the irrigation water and presents a more uniform distribution
$(\mathrm{H}=2.50 ; \mathrm{E}=0.92)$. In a more detailed analysis, comparing each location separately, no well defined patterns were observed. In the district of Campo Bom and Esteio the indices of diversity are greater in the irrigation water than in the drainage channel. In Caará the diversity is greater in the drainage water. The differences found, however, are caused by only a few species, which may be present or absent in any one location to a greater or lesser degree. For example, in Caará the difference between the irrigation and drainage waters is explained by the presence of four colonies of Serratia rubidaea. If we remove this species, the other diversity values of the two waters are similar. In the other locations we observed a greater diversity in the irrigation water channel.

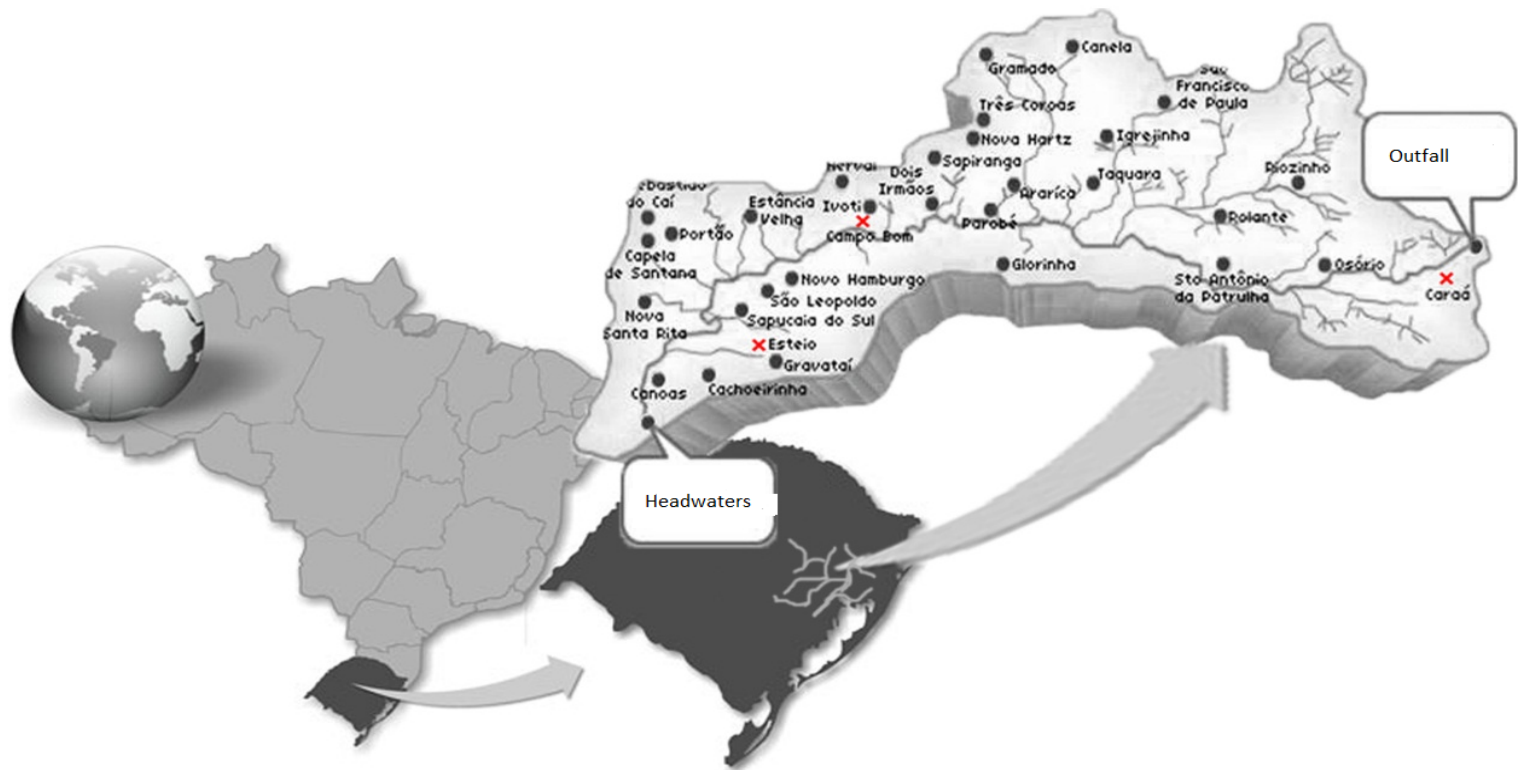

Figure 1. Map showing studied hydrographic basin and sampling sites

Table 1. Frequency of bacteria (UFC/100 ml) present in water samples from rice growing areas in the watershed of the Rio dos Sinos, agricultural year 2009/10

\begin{tabular}{|c|c|c|c|c|c|c|c|c|c|c|}
\hline Species & CA IR & CA LA & CA DR & CB IR & CB LA & CB DR & ES DR & ES LA & ES DR & UFCs \\
\hline Bacillus thuringienses & 6 & 2 & 2 & $\overline{4}$ & $\overline{5}$ & $\overline{9}$ & $\overline{5}$ & 3 & $\overline{4}$ & 40 \\
\hline Bacillus cereus & 2 & 1 & 3 & 5 & 3 & 1 & 3 & 6 & 1 & 25 \\
\hline Bacillus sphaericus & 0 & 1 & 0 & 1 & 0 & 0 & 0 & 1 & 0 & 3 \\
\hline Corynebacterium spp & 2 & 2 & 0 & 1 & 0 & 1 & 2 & 1 & 0 & 9 \\
\hline Lactobacillus spp & 2 & 2 & 2 & 2 & 0 & 2 & 0 & 0 & 0 & 10 \\
\hline Erwinia spp & 0 & 0 & 0 & 2 & 0 & 0 & 0 & 0 & 0 & 2 \\
\hline Aeromonas salmonicida & 0 & 0 & 1 & 2 & 0 & 0 & 1 & 0 & 0 & 4 \\
\hline Cryseobacterium indologenes & 0 & 1 & 1 & 1 & 1 & 0 & 1 & 1 & 0 & 6 \\
\hline Burkholderia cepacia & 1 & 0 & 0 & 1 & 0 & 0 & 0 & 3 & 2 & 7 \\
\hline Serratia fonticola & 0 & 0 & 0 & 0 & 0 & 0 & 0 & 2 & 1 & 3 \\
\hline Pseudomonas fluorescens & 2 & 0 & 4 & 3 & 0 & 0 & 3 & 3 & 0 & 15 \\
\hline Vibrio fluvialis & 0 & 1 & 1 & 0 & 0 & 0 & 0 & 0 & 1 & 3 \\
\hline Serratia rubidaea & 4 & 2 & 0 & 0 & 0 & 0 & 0 & 2 & 6 & 14 \\
\hline Pseudomonas putida & 0 & 0 & 1 & 0 & 1 & 0 & 0 & 0 & 1 & 3 \\
\hline Brucella spp & 0 & 1 & 0 & 0 & 0 & 0 & 1 & 0 & 1 & 3 \\
\hline klebisiella pneumoniae spp ozanae & 1 & 2 & 1 & 0 & 0 & 0 & 0 & 3 & 1 & 8 \\
\hline Pseudomonas aeruginosa & 0 & 0 & 1 & 0 & 0 & 0 & 1 & 0 & 0 & 2 \\
\hline Stenotrophomonas maltophilia & 0 & 0 & 1 & 1 & 0 & 0 & 1 & 0 & 0 & 3 \\
\hline Chryseobacterium meningosepticum & 0 & 0 & 0 & 0 & 1 & 1 & 3 & 0 & 0 & 5 \\
\hline Aeromonas hydrophila gr.1 & 0 & 0 & 0 & 2 & 0 & 0 & 0 & 0 & 0 & 2 \\
\hline Chromobacterium violaceum & 0 & 0 & 0 & 0 & 1 & 1 & 1 & 0 & 0 & 3 \\
\hline Number of species & 8 & 10 & 10 & 12 & 6 & 6 & 11 & 11 & 9 & \\
\hline Shannon & 1.904 & 2.246 & 2.245 & 2.322 & 1.540 & 1.297 & 2.213 & 2.151 & 1.908 & \\
\hline Evenness & 0.915 & 0.975 & 0.936 & 0.934 & 0.859 & 0.724 & 0.923 & 0.934 & 0.868 & \\
\hline
\end{tabular}




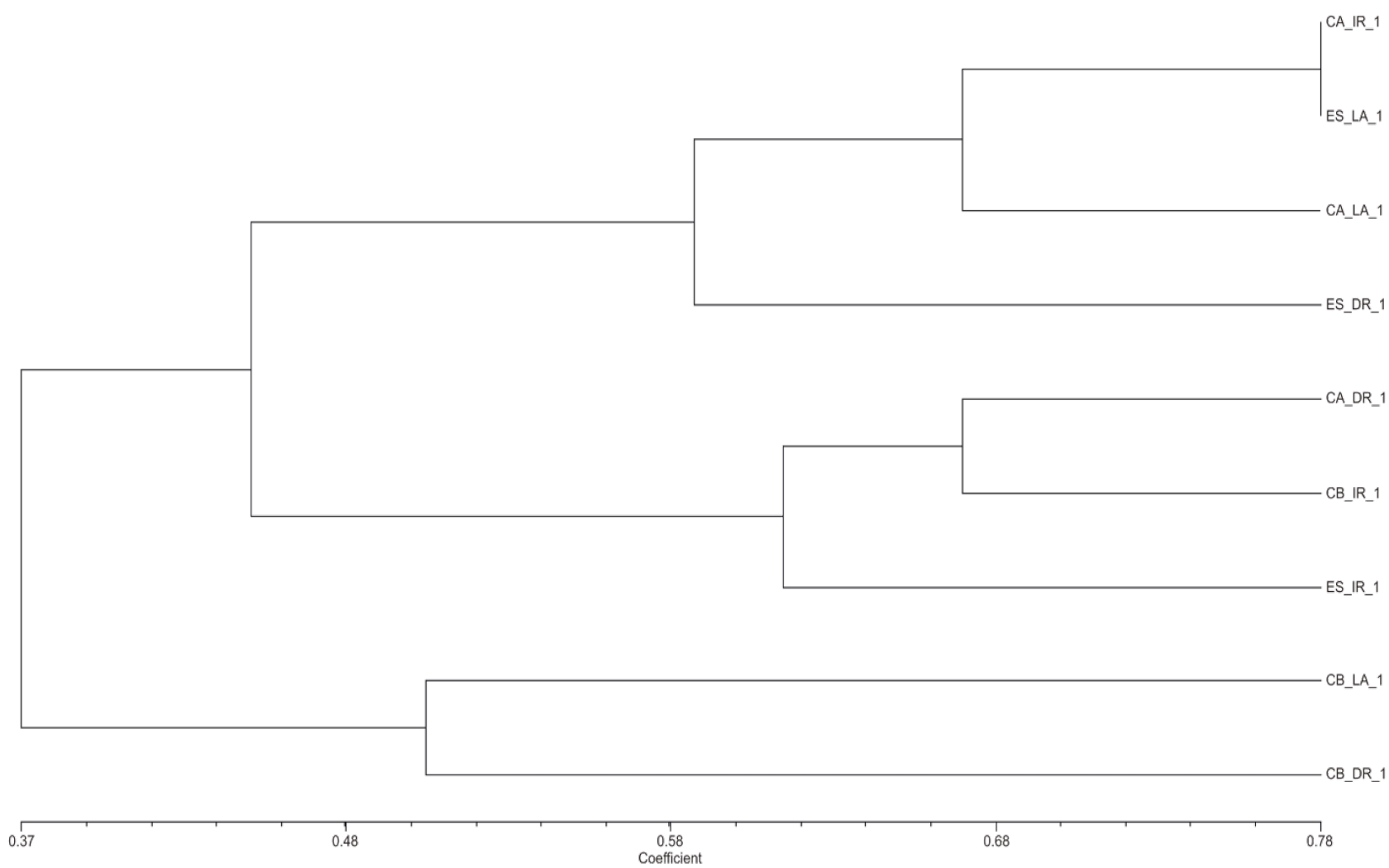

Figure 2. Dendrogram based on values for the Jaccard index showing the similarity of the bacterial communities in the sites sampled. Method of cluster analysis: UPGMA. $\mathrm{CA}=$ Caará, $\mathrm{CB}=\mathrm{Campo} \mathrm{Bom}, \mathrm{ES}=$ Esteio, $\mathrm{IR}=$ Irrigation channel, $\mathrm{DR}=$ drainage channel and LA= Rice Field

The species Chryseobacterium meningosepticum, Klebisiela pneumoniae, Lysinibacillus sphaericus, Erwinia spp. and Pantoea spp. were registered only in the irrigation channel water. Species observed only in the water around the plants were Acinetobacter baumanni and Ewingella americana, while only Ochrobactrum anthropi was found exclusively in the drainage water. The abundances of the colonies of Bacillus cereus, Pseudomonas fluorescens and Brucella $\mathrm{sp}$. of were greater in the water used for irrigation.

In order to obtain greater detail on the bacteria in the irrigation, field and drainage water we carried out two additional analyses: an analysis of similarity by the Jaccard coefficient and a Detrended Correspondence Analysis (DCA). In these two procedures we used only those species presenting more than five colonies in the total group of samples. (Table 1) The Jaccard similarity index reflects the similarity between locations based on the number of species they have in common (Figure 2). From these analyses we observed that, in samples from the same location, the irrigation (input) water and the drainage (output) water are always in different clusters. This is the principle observation we can make, in view of the fact that samples from different municipalities may be grouped in the same cluster, as happens with the irrigation water at Caará (Ca_IR_1) and the community from the cultivation water at Esteio (Es_La_1). Also, in the other clusters the similarities are around $6 \overline{0}$ and $68 \%$. The Jaccard index estimated values for the communities in the irrigation and drainage waters are less than 0.60 indicating a substantial difference in the presence or absence of the spe- cies[36].

The pattern observed in the phenogram that resulted from the application of the Jaccard index, appears also when we use the Detrended Canonical Analyzes (Figure 3). The auto-values generated for the first and second axis were 0.31 and 0.09 explaining $45 \%$ of the variance found. The first axis explains $35 \%$ and the second $10 \%$ of this variance.

The auto-values obtained in the CCA Analysis indicate the contribution of each axis to the explanation of the variation observed in the data. The auto-values for the first three axes of the CCA were 0.30, 0.19 and 0.12, respectively (Table 2). These three axes explain $70 \%$ of the variation in the distribution of the species; the first two axes explain $56 \%$ of the variation (Figure 4). The correlation species-environment for axis 1 indicates a good relationship between the species and the environmental variances utilized in the ordination. The Monte Carlo Test suggests that the probability that this ordination occurs by chance is low (Table 3 ). The variables of greatest importance for the ordination, correlated with the first axis, were the $\mathrm{pH}$ and Nitrogen (Table 3). The weighted co-relationships show inter-relationships with a few variables, as for example, between the $\mathrm{pH}$ and solids $(-0.62) ; \mathrm{pH}$ and Phosphorus (0.98); between Nitrogen and solids (-0.75) and between Phosphorus and solids (-0.68) The influence of the variables on the distribution of the species visualized in Figure 4 indicate; for eg. that the species $B$. cereus and Cryseobacterium indologenes are associated to the high values of $\mathrm{pH}$ and Nitrogen, while Serratia rubidaea and Vibrio fluvialis relate to lower values. 


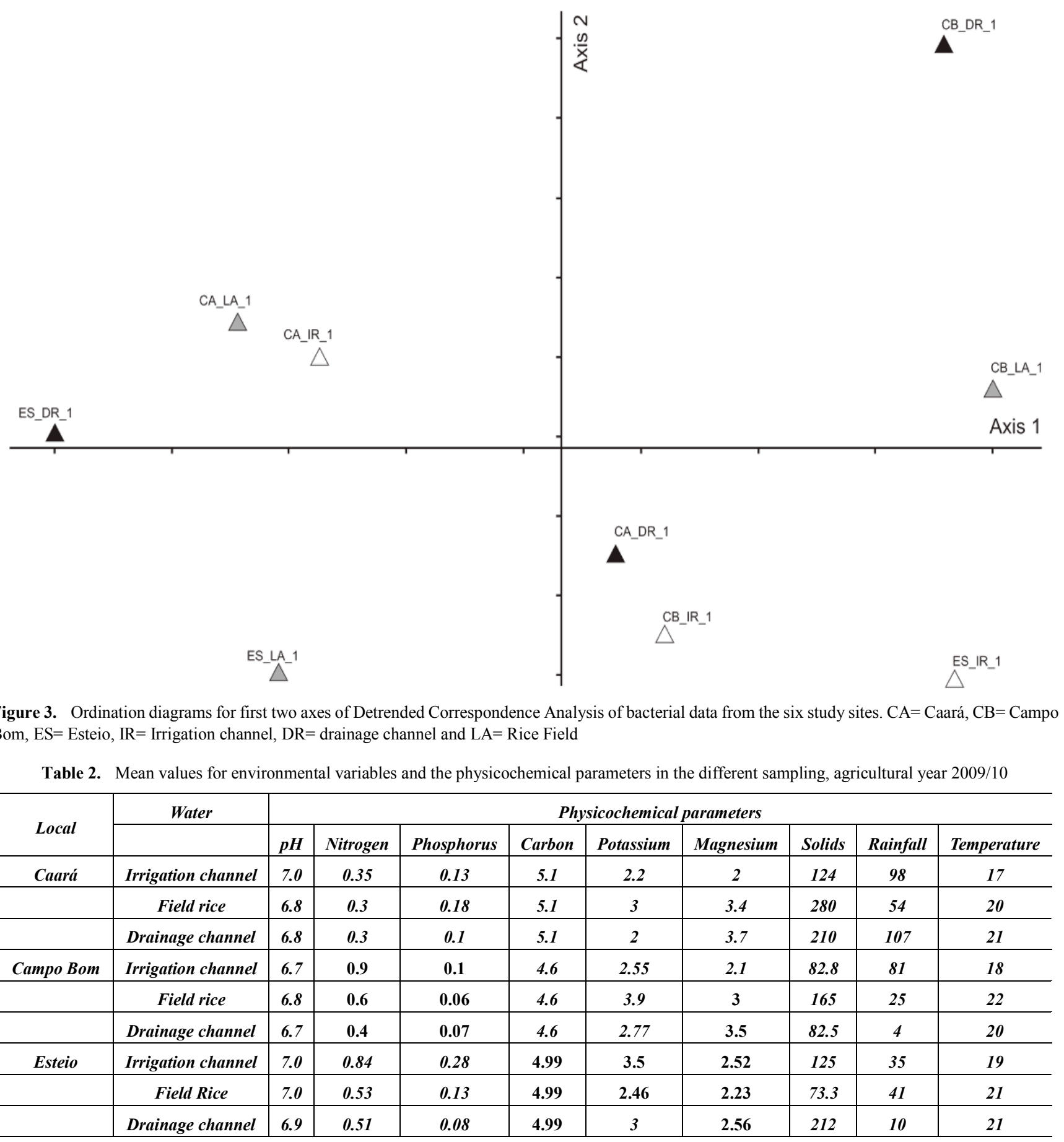

Table 3. Summary results of canonical correspondence analysis of the bacterial communities

\begin{tabular}{l|l|l|l}
\hline & Axis 1 & Axis 2 & Axis 3 \\
\hline Eingenvalues $(\lambda)$ & 0.308 & 0.192 & 0.126 \\
\hline Variance explained (\%) & 34.6 & 21,5 & 14.1 \\
\hline Cumulative \% explained & 34.6 & 56.1 & 70.2 \\
\hline Person correlation (Species- environmental) & 1.0 & 1.0 & 1.00 \\
\hline Monte Carlo test (p) & & & \\
\hline Eigenvalue & 0.001 & & \\
\hline Specie-environmental correlation & 0.01 & & \\
\hline
\end{tabular}




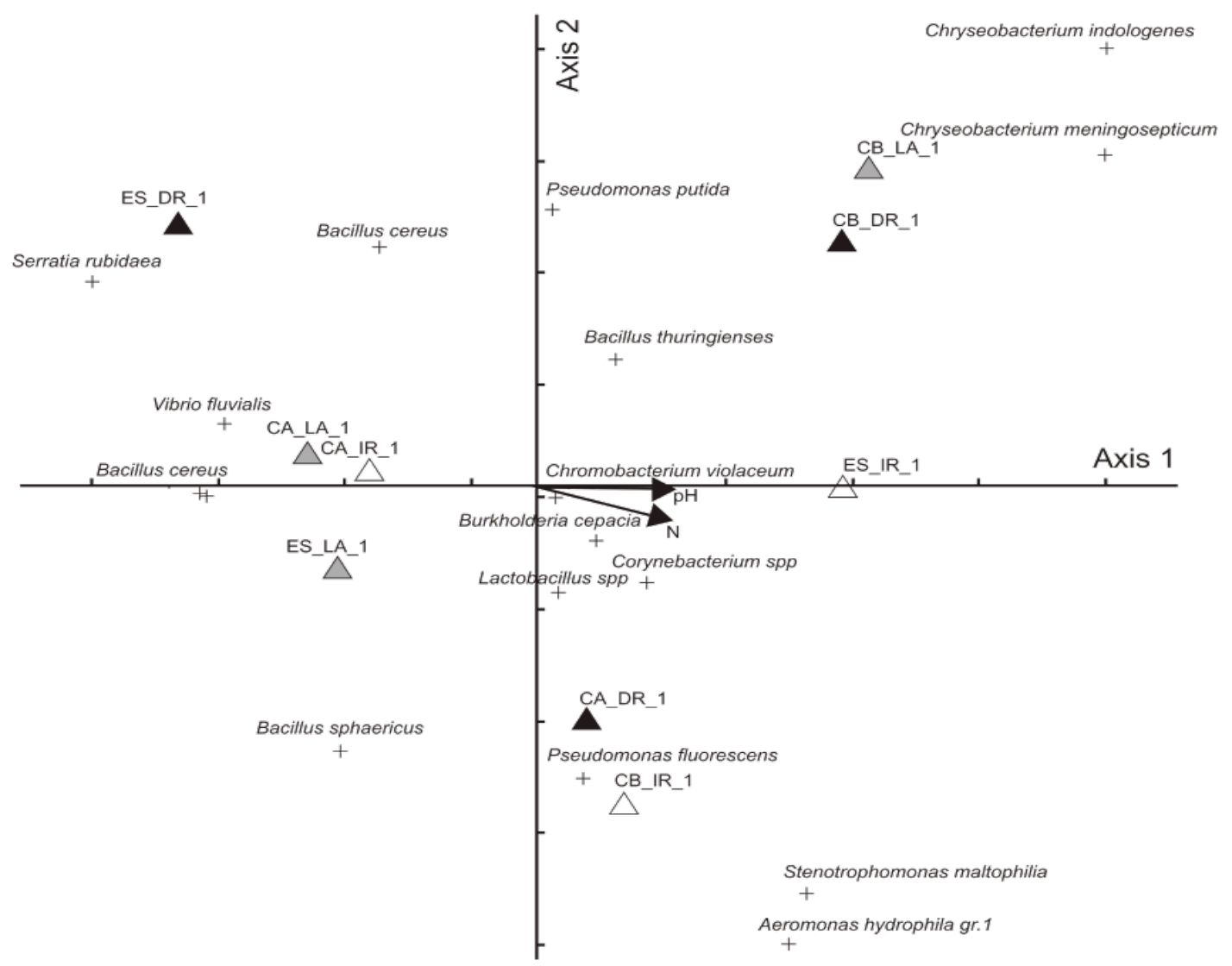

Figure 4. Canonical correspondence analysis $(\mathrm{CCA})$ ordination plots of sampling sites and environmental variables. $\mathrm{CA}=\mathrm{Caará}, \mathrm{CB}=\mathrm{Campo} \mathrm{B}$ m, $\mathrm{ES}=$ Esteio, $\mathrm{IR}=$ Irrigation channel, $\mathrm{DR}=$ drainage channel and LA= Rice Field

\section{Discussion}

The results obtained indicate that the bacterial communities analyzed are made up of many species, but few are abundant - as for example: Bacillus cereus, Bacillus thuringiensis, Psedomonas florescens and Lactobacillus spp. The bacteria found most frequently in the water samples analyzed are bacteria from the soil of rice fields, especially the genus Pseudomonas, Bacillus and Lactobacillus [37,38, 19]. The Bacillus thuringiensis species is the genus most often found in rice cultivation soils infecting various pests of the rice culture[39]. Its presence in the water associated to this culture was registered by Reche and Fiuza[20]. The bacteria of the Pseudomonas genus are an important soil group, especially because of their capacity to act as an endophytic, contributing significantly to the development of the plants[18,17].

Various studies have demonstrated the influence that the $\mathrm{pH}$ has in the composition and distribution of the species in bacterial communities[3,40,41,9,5]. Alterations in the $\mathrm{pH}$ can also cause alterations in other important chemical variations with which they are correlated, such as, for exampla, the heavy metals[42-45].

The impact of the increase in the availability of Nitrogen on the diversity of the communities has been studied in plants[46]. In general we observe a reduction of the number of species in the community[47,48]. The impacts of these elements on the bacterial communities in the soil are difficult to analyze and do not permit visualization of the patterns [49], although in some studies they are associated with a reduction of the biomass[50,51]. Studies have demonstrated that the Nitrogen level may influence the soil $\mathrm{pH}$, and this would have an important effect on the composition of the bacterial communities[52,53]. Studies realized in freshwater systems also indicate the influence that the availability of Nitrogen has on the bacterial communities $[54,5]$.

The results presented here demonstrate that cultivated bacteria diversity in the irrigation water entering a rice field is different to that same water when it leaves that field and returns to the supply source. This result can be interpreted in two different ways. On the one hand, this influence (of the plants on the water) may be considered negative as some of the species are not present in the water returned to the river/source. On the other hand, the quality of the water returned is improve as a reduction of some of the physical, chemical and biological parameters is observed[20]. However, in this context it is difficult to evaluate the degree to which management practices make a biological impact on the diversity of irrigated rice plantations because the levels of pollution in the irrigation water are above those observed in unpolluted environments.

The analyses realized are a contribution to the study of factors that influence the diversity of heterotrophic bacteria 
communities in paddy rice fields. Bearing in mind that the water utilized for irrigation contains concentrations of chemical and biological elements well above those in environments where the water is not polluted, it is impossible to determine whether the field management process commonly used in rice crop has a positive or negative effect on the bacterial communities. Even so, and besides the limitation of cultivation-dependent approach, studies such as the present document are relevant for the conservation and sustainable use of freshwater systems. Microorganisms are essential elements in the natural processes responsible for the quality of the water and therefore the acquisition of ever greater knowledge of the diversity of microbial system and of the factors influencing them is of considerable importance.

In this study we detected that the diversity of bacteria in rice field floodwater communities was influenced by nitrogen, $\mathrm{pH}$ and variables correlated. Relevant information is a reduction of the number of colonies for some species during the water passage by rice field. This reduction shows the ability of rice paddy field to filter some bacterial species improving the quality of returned water.

\section{ACKNOWLEDGEMENTS}

We acknowledge the Santander Bank (Brazil) S.A. by the financial support to do these research at Biology Graduate Program of UNISINOS. We thank our families, colleagues and friends. I thank my Lord Jesus Christ who died on the cross to save us.

\section{REFERENCES}

[1] Cavigelli MA, Robertson GP. The functional significance of denitrifier community composition in a terrestrial ecosystem. Ecology, 81: 1402-1414, 2000.

[2] Torsvik V, Daae FL, Sandaa RA. Novel techniques for analysing microbial diversity in natural and perturbed environments. J. Biotechnol, 64: 53-62, 1998.

[3] Sekiguchi H, Watanabe M, Nakahara T, Xu B, Uchiyam H. Succession of bacterial community structure along the Changjiang River determined by denaturing gradient gel electrophoresis and clone library analysis. Appl. Environ. Microbiol, 68: 5142-5150, 2002.

[4] Horner-Devine MC, Lage M, Hughes JB, Bohannan BJM. A taxa-area relationship for bacteria. Nature, 432: 750-753, 2004.

[5] Tian CJ, Tan X, Wu W, Ye X, Liu D, Yang H. Spatiotemporal transition of bacterioplankton diversity in a large shallow hypertrophic freshwater lake, as determined by denaturing gradient gel electrophoresis. J. Plankton Res, 31:885-897, 2009.

[6] Sood AKD, Singh PP, Sharma S.. Assessment of bacterial indicators and physicochemical parameters to investigate pollution status of gangetic river system of Uttarakhand (India). Ecol Indic, 8:709-717, 2008.
[7] Ramette A, Tiedje J. Biogeography: an emerging cornerstone for understanding prokaryotic diversity, ecology, and evolution. Microb. Ecol, 53: 197-207, 2007.

[8] Franklin R, Mills A. Introduction in the spatial distribution of microbes in the environment. Springer, New York, 2007.

[9] Wang Y, Shi J, Wang H, Lin Q, Chen X, Chen Y. The influence of soil heavy metals pollution on soil microbial biomass, enzyme activity, and community composition near a copper smelter. Ecotoxicol. Environ. Safety, 67: 75-81, 2007.

[10] Johnsen K, Jacobsen CS, Torsvik V, Sorensen J. Pesticide effects on bacterial diversity in agricultural soils: a review. Biol. Fertil. Soils, 33:443-453, 2001.

[11] Weber S, Stubner S, Conrad R. Bacterial populations colonizing and degrading rice straw in anoxic paddy soil. Appl. Environ. Microbiol, 67:1318-1327, 2001.

[12] Ibekwe AM, Kennedy AC, Frohne PS, Papiernik SK, Yang $\mathrm{CH}$, Crowley DE. Microbial diversity along a transect of agronomic zones. FEMS Microbiol, Ecol. 39:183-191, 2002.

[13] Dirk JE, Garbeva P, Salles J. Effects of agronomical measures on the microbial diversity of soils as related to the suppression of soil-borne plant pathogens. Biodegradation, 13: 29-40, 2002.

[14] Entry JA, Mills D, Mathee K, Jayachandran K, Sojka RE, Narasimhan G. Influence of irrigated agriculture on soil microbial diversity. Appl. Soil. Ecol, 40:146-154, 2008.

[15] Hengstmann UKC, Janssen PH, Liesack W. Comparative phylogenetic assignment of Environmental sequences of genes encoding 16S rRNA and numerically abundant culturable bacteria from an anoxic rice paddy soil. Appl. Environ. Microbio, 65: 5050-5058, 1999.

[16] Liesack W, Schnell S, Revsbech NP. Microbiology of flooded rice paddies. FEMS Microbiol. Rev, 24: 625-645, 2000.

[17] Weon H, Dungan RS, Kwon S, Kim J. The phylogeny of fluorescent pseudomonads in an unflooded rice paddy soil. Annals of Microbiology, 57: 299-306, 2007.

[18] Das J, Das B, Dangar TK. Microbial populations and Bacillus thuringiensis diversity in saline rice field soils of coastal Orissa, India. Afr. J. Microbiol. Res, 2:326-331, 2008.

[19] Rui J, Peng J, Lu Y. Succession of bacterial populations during plant residue decomposition in rice field soil. Appl. Environ. Microbiol, 75:4879-4886, 2009.

[20] Reche MHLR, Fiuza LM. Distribution and density of bacteria in subtropical flooded rice growing areas in Brazil. Braz. J. Biol, 65:503-511, 2005.

[21] Scavino AF, Menes JLF, Tarlera S. Bacterial community analysis of the water surface layer from a rice-planted and an unplanted flooded field. Braz. J. Microbiol, 41: 411-419, 2010 .

[22] Barreiros L, Manaia CM, Nunes OC. Bacterial diversity and bioaugmentation in floodwater of a paddy field in the presence of the herbicide molinate. Biodegradation, 22:445-460, 2011.

[23] Sosbai Arroz irrigado: recomendações técnicas da pesquisa para o sul do Brasil. Sociedade sul-brasileira de arroz irrigado. Pelotas: XXVII reunião da cultura do arroz, 1: 13-154, 2010. 
[24] Rhee HP, Yoon CG, Son YK, Jang JH. Quantitative risk assessment for reclaimed wastewater irrigation on paddy rice field in Korea. Paddy Water Environ, 9:183-191, 2010.

[25] Furtado DF, Luca SJ. Técnicas de cultivo de arroz irrigado: Relação com a qualidade de água, protozoários e diversidade fitoplanctônica. R. Bras. Eng. Agríc. Ambiental, 7: 165-172, 2003.

[26] Macedo VRMM, Menezes VG. Influência dos sistemas de produção e manejo no uso da água pela planta de arroz. In Universidade de Passo Fundo (eds), Uso da água na agricultura, Passo Fundo DC. pp. 1-20, 2004.

[27] Holt JG, Krieg NR, Sneath PHA, Staley JT, Williams ST. Bergey's manual of determinate bacteriology. Baltimore, William and Wilkins, 1994.

[28] Tedesco MJ, Gianello C, Bissani CA, Bohnen H, Volkweiss SJ. Análises de solo, plantas e outros materiais. Boletim Técnico de solo da Universidade Federal do Rio Grande do Sul, 1995.

[29] Magurran AE. Measuring biological diversity. Oxford, Blackwell, 2004.

[30] Rohlf FJ. NTSYS 2.1: numerical taxonomic and multivariate analysis system. Exeter Software, NY, 2000.)

[31] Jongman RHG, Ter Braak CJF, Van Tongeren OFR. Data analysis in community and landscape ecology. Cambridge: Cambridge University Press, 1995.

[32] Legendre P, Legendre L. Numerical Ecology: developments in environmental modelling. Amsterdam, Elsevier, 1998.

[33] Ter Braak CJF. Ordination In: Jongman, R. H. G., C. J. F. Ter braak \& O. F. R Van Tongeren (eds), Data analysis in community and landscape ecology. Cambrigde, Massachusetts DC, 1995.

[34] McCune B, Mefford MJ. PC-ORD for Windows: multivariate analysis of ecological data, version 3.17. MjM Software, Gleneden Beach, Oregon, U.S.A, 1997.

[35] Rahel FJ. The hierarchical nature of community persistence: a problem of scale. Am. Nat, 136: 328-344, 1990.

[36] Nakayama N, Okabe A, Toyota K, Kimura M, Asakawa S. Phylogenetic distribution of bacteria isolated from the floodwater of a Japanese paddy field. Soil Sci. Plant. Nutr, 52: 305-312, 2006.

[37] Asaki N, Ishihara R, Nakajima Y, Kimura M, Asakawa S. Succession and phylogenetic composition of eubacterial communities in rice straw during decomposition on the surface of paddy field soil. Soil Sci. Plant Nutr, 53: 56-65, 2007.

[38] Theunis W, Aguda RM, Cruz WT, Decock C, Peferoen M, Lambert B, Bottrell D, Gould FL, Litsinger JA, Cohen MB. Bacillus thuringiensis isolates from the Philippines: habitat distribution, dendotoxin diversity and toxicity to tem borers (Lepidoptera: Pyralidae). Bull. Entomol. Res, 88:335-342, 1998.

[39] Yannarell AC, Triplett EW. Geographic and environmental sources of variation in lake bacterial community composition. Appl. Environ. Microbiol, 71:227-239, 2005.

[40] Lindstrom ES, Kamst-Van-Agterveld MP, Zwart G. Distribution of typical freshwater bacterial groups is associated with $\mathrm{pH}$, temperature, and lake water retention time. Appl. Environ. Microbiol, 71:8201-8206, 2005.

[41] Methe BA, Zehr JP. Diversity of bacterial communities in Adirondack lakes: do species assemblages reflect lake water chemistry? Hydrobiologia, 401:77-96, 1999.

[42] Muylaert K, Gucht K, Vloemans N, Meester L, Gillis MV. Relationship between bacterial community composition and bottom-up versus top-down variables in four eutrophic shallow lakes. Appl. Environ. Microbiol, 3: 4740-4750, 2002.

[43] Percent SF, Frischer ME, Vescio PA, Duffy EB, Milano V, McLellan M, Stevens BMB, Charles W, Bauer SA. Nierzwicki-Bacterial community structure of acid-impacted lakes: what controls diversity? Appl. Environ. Microbiol, 74: 1856-1868, 2008.

[44] Akmal M, Xu J. Microbial biomass and bacterial community changes by pb contamination in acidic soil. J. Agr. Biol. Sci, $1: 30-37,2009$

[45] Gough L, Osenberg CW, Gross KL, Collins SL. Fertilization effects on species density and primary productivity in herbaceous plant communities. Oikos, 89: 428-439, 2000.

[46] Suding NS, Collins SL, Gough L, Clark C, Cleland EA, Gross KL, Milchunas DG, Pennings S. Functional-and abundance-based mechanisms explain diversity loss due to $\mathrm{N}$ fertilization. PNAS, 102: 4387-4392, 2005.

[47] Gilliam F S. Response of the herbaceous layer of forest ecosystems to excess nitrogen deposition. J. Ecol, 94:1176-1191, 2006.

[48] Treseder KK. Nitrogen additions and microbial biomass: a meta-analysis of ecosystem studies. Ecol Lett, 11:1 111-1120, 2008.

[49] Ruppel S, Torsvik V, Daae FL, Ovreas L, Rühlmann J. Nitrogen availability decreases prokaryotic diversity in sandy soils. Biol. Fertil. Soils, 43: 449-459, 2006.

[50] Zeglin L, Sturova M, Sinsabaugh RL, Coolins SL. Microbial responses to nitrogen addition in three contrasting grassland ecosystems. Oecologia, 154:349-359, 2007.

[51] Lauber CL, Hamady M, Knight R, Fierer N. Pyrosequencing-based assessment of soil $\mathrm{pH}$ as a predictor of soil bacterial community structure at the continental scale. Appl. Environ. Microbiol, 75: 5111-5120, 2009.

[52] Ramirez KS, Christian LK, Rob B, Mark AFN. Consistent effects of nitrogen fertilization on soil bacterial communities in contrasting systems. Ecology, 91:3463-3470, 2010.

[53] Chróst R, Adamczewski T, Kalinowska A. Inorganic phosphorus and nitrogen modify composition and diversity of microbial communities in water of mesotropic lake. Pol. J. Microbiol, 58:77-90, 2009.99. 